\title{
THE ART OF WAYFINDING PASIFIKA SUCCESS
}

\author{
Jacoba Matapo* \\ Tim Baice ${ }^{\dagger}$
}

\begin{abstract}
The notion of "success" for Pasifika students in higher education remains contested given the sociopolitical agendas of education in New Zealand targeting Pasifika engagement. The motivation to increase academic achievement for Pasifika peoples stems from "tail-end" outcomes, in which Pasifika populations are compared with other demographic populations in the attainment of higher qualifications. Many institutional "success" strategies are initiated essentially from a deficit positioning, to respond to barriers of participation, and ensure academic progression and student completion. While such aspirations may seem advantageous for Pasifika learners, the complexity lies in how such strategies shape Pasifika learner identity and subjectivity within institutions. In this article, the tensions for Pasifika success are argued from a position of decolonising education through honouring cultural onto-epistemology (practices of knowing-in-being) and relating to the world, thus challenging motivation for engagement with Pasifika learners as strength based rather than a deficit response. The art of engagement with traditional wayfinding tools designed for teaching and learning is utilised as a way of generating and reconceptualising notions of Pasifika success as Pasifika.
\end{abstract}

\section{Keywords}

Pasifika, higher education, equity, success, wayfinding, Indigenous

\section{Introduction}

This article draws upon a collective project called "He Vaka", a teaching and learning initiative established at the University of Auckland to support Māori and Pasifika student achievement. $\mathrm{He}$ Vaka brings together Māori and Indigenous Pacific worldviews in an attempt to decolonise spaces and places of learning within the institution. This article can be viewed as part of a whole, as it draws upon political, social and historical tensions identified within other research projects in this special issue. The intentional engagement with Pacific Indigenous navigational knowledge (as embodied) opens opportunities for re-imagining success as
Pasifika within the academy. Before moving on, it is important to distinguish the difference between Pacific and Pasifika as presented within this article. Pasifika refers to Pacific peoples living in Aotearoa, while Pacific specifically ties to Pacific ethnic and cultural connections to Pacific Island homelands genealogy (of people and knowledge).

The term Pasifika in an education context was introduced by the Ministry of Education (Pacific leadership) in the mid-1990s to ensure that only those of Pacific ancestry could access Pacific teacher education study awards. Since then, the term Pasifika has been contested by Pacific scholars as homogenising, as it groups together Pacific

* Associate Dean Pasifika/Senior Lecturer, School of Critical Studies in Education, Faculty of Education and Social Work, University of Auckland, Auckland, New Zealand. Email: j.matapo@auckland.ac.nz

$\dagger$ Pasifika Success Coordinator, School of Critical Studies in Education, Faculty of Education and Social Work, University of Auckland, Auckland, New Zealand. 
Islands peoples living in New Zealand (either New Zealand born or migrant) and is not ethnic specific (Finau, 2014). Other Pasifika scholars have reconceptualised the term Pasifika to represent a symbol of unity rather than a homogeneous grouping of Pacific Islands peoples (Samu, 2006).

Featured throughout this article is wayfinding and the relationship to Moana Nui as a life force that also connects Māori and Pasifika people, rather than visioning waters as a separating of lands (Hau'ofa, 2008). In this spirit, we present navigation and wayfinding as an art that affirms and generates connection, where the collective (relational self tied to place, ancestors, people) may thrive. Throughout this article, we present local and global debates regarding the representation of Pacific peoples in higher education, the impact of deficit theorising and the need for decolonising of personhood and the neoliberal institution. Neoliberal ideals have increasingly determined measures of success in higher education, from the guise of free choice, to the commodification of education and knowledge transfer. We challenge the human subject position as value-free and universal, and confront dominant notions of success presented within literature, policy and equity initiatives. The shared (re)conceptualisations of Pasifika students and Pasifika staff within the Faculty of Education and Social Work at the University of Auckland are presented throughout, in visuals of shell maps, and through poetry and narrative.

\section{Methodological considerations}

From the beginning, this research project sought a decolonising agenda: to inform engagement in all phases to be conducive to Pacific cultural onto-epistemology. Onto-epistemology brings together ontology of being and nature of knowledge, bridging a divide between dualisms of mind over matter (such as Cartesian mind-body dualism) and contests the dominant human subject position presented in the "great chain of being" (a presupposition that separates the human subject from cosmos and cosmogony). The processual movement and flows in relation to the body, mind and material evoke an embodied (embodiment sense) approach of interaction within this project, intersecting with subjectivity, Pacific histories, traditional Pacific knowledge(s) and contemporary Pacific research methodology.

Decolonising research calls for radical change in political and social environments (Smith, 2012). The decolonising movement confronts the assumptions on which colonialism is based, to arrive at transformation of the social and political order. Indigenous peoples must be active agents, sharing common goals that arise from lived experience of colonialism. Self-determination as understood by Indigenous societies is a key feature in the fight against the impeding forces of globalisation of Indigenous cultures, society and knowledge. Thus, research must raise public awareness of the diversity of Indigenous lifeways, thus sustaining Indigenous rights and empowerment (Smith, 2012). This research seeks to honour Pacific Indigenous ways of being and knowing to engage in generative and emergent reconceptualisations of success as Pasifika within the university. Highlighted within the study are the political tensions for equity and parity, which remain enmeshed in navigating success within the institution. Accordingly, this article presents the political context for Pasifika student achievement in higher education and emphasises the complexities of Pasifika engagement as an equity focus and tensions of parity under the guise of diversity.

In this study, engagement in arts practice creates generative and emergent ways of being-in-knowing in which traditional wayfinding materials and the process of making shell maps evoke storying of histories and culture, and the sharing of different realities. The act of reconceptualising by way of a social arts practice opened opportunities for a collective mapping of "notions of success" in which the shell maps were collective creative expressions. The process of reconceptualising requires deep questioning of taken-for-granted truths, an openness to experiential engagement with world (materiality and) complexity to make and remake meaning (Matapo \& Roder, 2017; Pinar, 1995). Bringing together social arts practice with talanoa (explained later), provided our Pasifika kainga and students with an experience to sense, question and dialogue our experiences as Pasifika (students and academics) succeeding within the university.

As Pasifika academics within the Faculty of Education and Social Work specialising in Pasifika education and research, we position ourselves within a relational praxis-engaging collectively with Pasifika colleagues and students in culturally sustaining practice. As part of the decolonising agenda, we call into question the humanist position privileged in qualitative research and enact a Pacific onto-epistemology in which knowing is not only subject to human condition such as constraints in rational thought, ordered thinking (a priori) and representationalism (Mika \& Matapo, 2018). The intentional engagement with traditional wayfinding materials in art-making 
provokes sense as knowing-knowing that is grounded in the belly, knowing that escapes stratified language signification (Matapo, 2018; Spiller et al., 2015). Thus, the article presents various explorations of Pasifika success as visual provocations, the sharing of Pasifika academic and student narratives and storying through poetry.

\section{Decolonising personhood: Researcher-in-research}

By way of decolonising and heeding the invitation set out by Vaai and Nabobo-Baba (2017) to increase the need to revisit personhood, we, the authors of this article, share with you, the reader, our research journey. Here, we express researcher positionality, a personal narrative of researcher considerations engaged in and with research.

\section{Jacoba Matapo}

Being a New Zealand born Samoan and Pasifika early childhood education lecturer, I am continually faced with tensions advocating for marginalised Pacific Indigenous knowledge and pedagogy within a predominant Western ideologically based education sector. Although I intentionally and critically locate myself within a typically Western paradigm of education, I continue to contest dominant discourses that privilege themselves and continue to marginalise Indigenous knowledge (Matapo, 2018). Through my relationships, interactions and experiences within broad education contexts (early childhood, primary school and tertiary), I have become increasingly critical of taken-for-granted truths, notions of the universal human subject and how this influences the place of valued knowledge(s) in education and education research.

Through my engagement in Pasifika education research, I have been able to traverse Pacific Indigenous thinking, such as the relationship of human subjectivity to cosmogony, Pacific creation stories (Matapo, 2019). Pacific philosophy has challenged me to think differently about the spatio-temporality of being and is significant to me personally, as I operate to decolonise education and Pacific research from a location other than my ancestral lands of Siumu, Samoa. I have grown an affinity to specific places, my maunga, my awa, my shared connection with whenua and lasting relationships with tangata whenua. Through Pacific research and by way of storying, I am coming to understand and reconceptualise the collective histories of Māori with tangata o le Moana in my own becoming.

\section{Tim Baice}

Originally from the villages of Sataoa-Safata and Siufaga-Falelatai, I have spent most of my adult life immersed in the heart of Aotearoa's Pacific capital (Mangere). This fusion of multiple structural factors (cultures, traditions, knowledge and patterns of knowing) is simultaneously different-at times conflicting and at other times harmonious, as they shape and continue to mould my Pacific itulagi (Vaai \& Casimira, 2017).

As an "equity practitioner" in higher education, I occupy a role designed to support Pacific students by constructing interventions infused with Pacific cultural values. Here, I am constantly challenged with the task of privileging multiple Pacific itulagi within the confines of the "neoliberal university". Within the academic context, we work with students to reconsider and reframe their thinking in multiple ways. Concurrently, we encourage those in academic and professional roles to reconsider and reframe their ideas about Pacific education and equity of provision. Central to this process of decolonising the academy is the validation of Pacific epistemologies (Si'ilata, 2014) and the legitimising of "relationality" as key to Pacific success (Vaai \& Casimira, 2017).

Such challenges transcend the walls of the university. They provide the context in which Pacific itulagi are contested and negotiated at the national and regional level. My advocacy work here in Aotearoa, Samoa and across the region frames my positionality as a citizen of the Pacific-a notion that goes beyond geographic and political boundaries, which speaks to a relational interconnectedness that is bound by a common cause to champion all things Pacific.

\section{Talanoa and shell map making: Art of wayfinding}

The meaning of talanoa is explained as tala"talk", and noa- "nothing in particular" (Vaioleti, 2006). The complexity of talanoa lies within deeper ethical relations (to concepts and people) as a condition and milieu for the creation of knowledge that is socially constructed. Talanoa, as explained by Farrelly and Nabobo-Baba (2012), has potential for emergent and different ways of thinking and as an embodied and embedded approach with Pacific Indigenous knowledges. Talanoa is a relational and dialogic methodology, considerate of the intricate multiplicities conceived and reconceived in the social space, which draws connections rooted within Pacific oratory histories (Vaioleti, 2006). Trust within the practice of talanoa creates capacity for the 
sharing of feelings, inner stories, and experiences that speak to our hearts and mind (Farrelly \& Nabobo-Baba, 2012). The act of talanoa within this study intersects with collective arts practice, engaging all involved in the creation of shell maps as a provocation for dialogue and reconceptualising of Pasifika success within the university. As Samoan Pasifika researchers drawing upon Micronesian navigation tools, we are critical of our positionality (neither of us have Micronesian ties); however, we value the shared genealogical connection of Pacific navigation knowledge(s). In this spirit, we wish to engage the social and relational nature of Pacific wayfinding arts practice as a woven socio-historical fabric of cultural expression, where peoples and materials share story of place, connection and genealogy. The shell maps through talanoa became a reconceptualisation of political, cultural and critical expression.

In the Pacific, teaching the art of wayfinding included specific tools that engaged learners with the complexities of navigation. One such tool is known as the Marshall Islands shell map (rebbilib or meddo) which plots islands, ocean swells, currents and refraction of ocean swells. The meddo shows the swell patterns of a few islands and the rebbilib covers a larger part of the whole archipelago (Lewis, 1994). The rationale for the selection of the Marshall Islands (Micronesian) shell map or Marshallese stick chart is in the experiential arts process of teaching and learning. Traditionally, the expert or master navigator would use the shell map to teach the novice navigator about the ocean swells and islands (Genz, 2018). Pacific Indigenous navigation flows out of a belief in sacred kinship with all of creation and a deep sense of belonging in an interrelated woven universe. At the heart of Indigenous navigation knowledge is a spiritual core-a belief in "co-evolution" whereby humans did not evolve only in relationship to each other, but that all of creation co-evolved in a symbiotic spiritual exchange, and we all connect to a shared origin (Spiller et al., 2015). We are reminded of the "embodied" nature of navigation as a way of being with, in and through the world-the body and nature multiplicity. Wayfinders can use

the whole body as a perceptive instrument, attuning to the changing and often seemingly imperceptible signs of nature. They move with purposeful stillness, and know the world around them as they know themselves. Theirs is a highly disciplined way based on using all of their senses and different types of intelligence to truly "see" what is going on-and processing these signs to understand the relationships between them. (Spiller et al., 2015, p 17)

It is important to note that, traditionally, the shell map was not taken out on the water; it was used on land as a process of learning the ebbs and flows of the water (encouraging engagement with body and mind as perceptive instrument), to be memorised, to be a visionary tool. Through this processual engagement, we explore the markers (shell map markers) of success as Pasifika. Shell markers, as focal points within the maps, referred

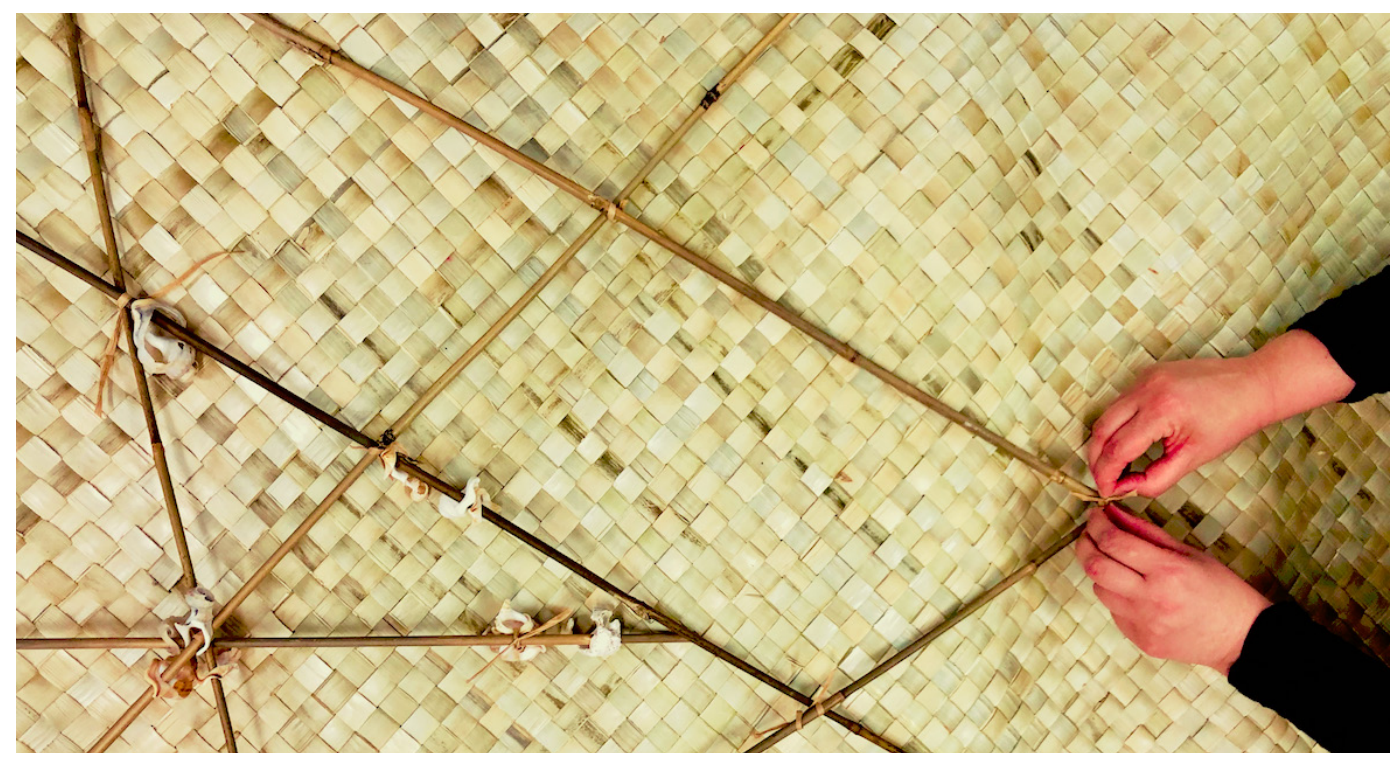

FIGURE 1 Faculty of Education and Social Work-Pasifika Kainga and Pasifika students' shell maps 
to cultural, personal and collective values; aspirations such as tautua, spirituality, aiga, collective responsibility, ancestors, Indigenous knowledge, resilience and connections to ancestral lands were explicitly conveyed. As Pasifika staff and students connected their stories, experience and critique of Pasifika success in the academy to the shell map markers, an assemblage of wayfinding Pasifika success with Indigenous navigation knowledges emerged. There is a sense that knowing success is grounded in knowing context, knowing the body (feeling the right direction), and knowing the environment and political landscape. We would argue that this is inclusive of the socio-historical context and hidden agendas of education and education policy. A Pasifika student and a Pasifika staff member expressed the following:

We must go by the waves, you can see and feel the right direction to take, the path that will bring you success. (Pasifika staff)

The shell maps are about understanding how our people navigated through the seas but relating it to how we are navigating our way through study. (Pasifika student)

Following the talanoa, a Pasifika staff member was asked what was most significant to them during the talanoa. In her response, she expressed particular tensions for Pasifika aspirations to succeed as Pasifika. The aspirations or ideal (presented in the shell map) were indeed different from the lived reality. She said:

The sense of connection. Also, the challenges of connecting the past to the present and reconceptualising traditional practices to something that is real and relevant juxtaposed to an ideal that seems far removed from what we are experiencing. (Pasifika staff)

\section{Privileging Indigenous knowledge}

Pre-colonisation Pacific philosophical and theological thought is grounded upon its relation to all things; monotheism and cosmogony directly influenced the Pacific collective constructions of knowledge and spirituality is encompassed in ways of knowing (Hau'ofa, 2008; Matapo, 2018). The impact of colonisation upon the Pacific body of knowledge has changed what before was immanence in the generation of knowledge (the creation of new images of thought in relation to all things-material, human and non-human) to a transcendental epistemology (based upon
Christian values and beliefs). There is a strong presence within the Pasifika research literature of a blending of Christian values with Pacific ways of being (Anae et al., 2001), which was also present through the shared values, beliefs and cultural connections made throughout each of the talanoa and shell map making experiences.

In the sharing of narratives expressed through talanoa and shell map making, it is evident that Pacific cultural knowledge, as nomadic, travels to enable new identity formations, and belonging within the university institution is no exception. We question how cultural knowledge that is nomadic and open to relations of change deterritorialises and reterritorialises (Deleuze \& Guattari, 1987) notions of success that are taken for granted within the institution. The process of talanoa and shell map making calls upon shared histories, connection and an affinity with Moana Nui to bring together Pasifika peoples, and Indigenous knowledge, histories and genealogies. Using the words of Manulani Meyer (2014), we reflect upon the capacities of Indigenous knowing:

It is time to expand the discussion of knowledge with a more ancient capacity linked to land, water, people, and language. Time to extend knowing beyond cognitive accumulation perfectly rendered in textual form. Here is a space for mindfulness to enter the academy via chant, insight and spirit. We are long overdue for intelligence that recognises patterns of continuity and remembers the purpose of culture. (p. 157)

Along with ancient capacities to know that extend beyond cognitive accumulation, we argue for self-determination against colonising naming of Indigenous peoples that engender political and systemic intentions to fix definitions of specific ethnic groups. The complexities for Pacific peoples living in Aotearoa away from ancestral lands, yet connected to ancestral lands, ties to people and culture demonstrating strength and resilience in collective responsibility and care. From here, we question how education regimes continue to marginalise Pacific Indigenous onto-epistemology and what this means for Pasifika peoples continuing to negotiate education and education politics. Re-imagining the human subject as generative and emergent becoming(s) rather than a universalised subject may change dominant views of success in education. One Pasifika student expressed her connection to the collective and appreciation for organic material as a symbol of Indigenous knowledge. She went on to say: 
When I look here [at the shell maps], they're kind of grids, and so students from this collective can have different pathways and if you look at the symbolism of the top being the epitome of success, whatever that looks like, these are how you get there, different pathways, but you still come from this collective, and I think that in some ways, the fact that it's all organic material, like particularly green leaves, that's got to be indicative of what feeds us in terms of our Indigenous knowledge. (Pasifika student)

\section{Pasifika success: What does the discourse tell us?}

We move into notions of Pasifika success targeted at Pasifika students within Aotearoa. As a minority ethnicity group and like minority ethnic groups globally, Pacific students in the context of higher education in New Zealand are more prone to unfavourable stereotypes or "stereotype threat" (Allen \& Webber, 2019) whereby they are typically deemed "less able", "less intelligent" and (comparatively) "academically" disengaged (Hunter et al., 2016). Connected to stereotype threat are the ensuing effects of low teacher expectations. Teachers in Turner et al.'s (2015) study cited deficits in Pacific students' home backgrounds that lead to a lack of goals, motivation and aspirations in education. These perceived deficits were suggested as being responsible for the gap in academic achievement. Such perceived deficits are often adapted by students, who in their socialisation within a given context internalise paradigms of failure, which leads to a distortion of wider possibilities for success (Walker, 2006). Furthermore, Pacific students have been marginalised by inequitable teaching practice, cross-cultural misunderstandings and deficit theorising by educators (Hunter et al., 2016). The tensions presented in the literature are also relevant to the challenges faced by students. To mitigate such deficit conceptualisations, Pasifika students suggested:

Success for Pasifika needs to be defined by Pasifika people. (Pasifika student)

Tula'i, means to arise, not as individuals but as one-as a collective. (Pasifika student)

Another Pasifika student echoed the call to confront such deficit theorisations of Pacific peoples:

Pasifika success means a lot coming from Pasifika . . . as we are known stereotypically for not passing in academics, but achieving highly out on the sports field! However, being Pasifika means carrying your ancestors with you, as you have big support group behind you, they maybe struggled significantly and it is the push factor for Pasifika success. (Pasifika student)

Defining success for Pacific students in higher education is complex, given the need to consider holistically how success is determined. On the one hand, it requires a holistic approach to fully understand the relativity of any success to the multiple worlds they operate within (Si'ilata et al., 2018). Academic success is seen as the fruit of a collective effort, in which Pacific students are supported heavily by peers, families and communities. Success contributes to the well-being of the collective and shows that success has both internal and external impacts (Mayeda et al., 2014). Pasifika success viewed as a holistic practice was also conveyed in the talanoa:

Success is about my whole hauora, you know, it is about balance. (Pasifika student)

The literature on effective teaching and learning practices for Pacific learners in higher education features a variety of small-scale case studies focused on equity-funded initiatives (Airini et al., 2009; Airini et al., 2011; Chu et al., 2013; Curtis et al., 2012; Hunter et al., 2016; Lafaialii, 2012; Mayeda et al., 2014; Patterson, 2012; Williams, 2009). See Universities New Zealand (2018) for a list of equity-funded projects. The initiatives are almost exclusively funded by the Tertiary Education Commission (TEC) Education Fund, also largely positioned outside of formal programme and course structures. Such approaches to effective teaching and learning for Pacific students lacks systemic engagement with deeper issues, such as subjugation of Pacific ways of being and knowing within the academy. From an institutional perspective, success for Pacific learners is defined as academic achievement rates on par with their Pākehā counterparts. Characteristic of contemporary education policy, parity for Pacific learners is also underpinned by a strong economic focus. This is mandated by projections that Māori and Pacific communities will constitute $30 \%$ of the working population in 2030 and the recognition that, historically, both groups have been underserved by the education system (TEC, 2018). Estimations from Universities New Zealand (2018) based on census data and statistical projections show that if parity is achieved in the education sector, this will generate an extra $\$ 123$ million and 
\$55 million in the Māori and Pasifika economies respectively.

\section{The neoliberal university and equity}

Equity is a contested term in its meaning, understanding and practice (Barrow \& Grant, 2019). This difference in nuance shapes institutional policy framing and implementation differently. In higher education, the most prevalent differences are between the understanding of equity as either "fairness" or "inclusion"-in which the former refers to increasing absolute representation of underrepresented groups and the latter refers to a proportional representation of underrepresented groups to their broader proportion in wider society (Marginson, 2011). Moreover, "equity as fairness" refers to policies of redistributive justice, and "equity as inclusion" refers to policies that seek to redress (ameliorate) inequities in higher education (Savage et al., 2013). On this note, Salmi and Bassett (2014) define equity as the provision of "equal opportunities for access and success in tertiary education" (p. 365). They distinguish this from the concept of "equality", arguing that equity is not bound by the same commitment to treat everyone the same. Equity recognises difference and is a means of providing "interventions" that promote equal opportunity (p. 365).

Equity in higher education is a direct result of the emergence of the neoliberal imperatives to build human capital (knowledge and education) and strengthen the commodification of knowledge (Barrow \& Grant, 2019). This follows a global trend in which higher education reforms (including privatisation, marketisation and internationalisation) have reduced education to a commodity, to be bought and sold (Sakhiyya \& Rata, 2019). At the heart of a "knowledge economy" is the production and sale of knowledge. Under these imperatives, higher education institutions have become key drivers of (national) economic development (Sakhiyya \& Rata, 2019). Equity_framed by theories of neoliberal economic developmentthen become the means by which (equitable) participation in higher education for all is enabled.

Under the competitive nature of the global knowledge economy, universities have traditionally acted as screens, ensuring intense competition for limited places, restricting participation and success to those who have the capital (means) to succeed (Espinoza, 2010). The shift in the idea of higher education as a public good versus a private commodity captures the troubled place of equity in the university. As higher education institutions have intensified their neoliberal outlook, remnants of the ecological model of universities are struggling to remain true to their altruistic origins. Commitments to achieving social justice, equality, equity and human rights are undermined by the prioritisation of expanding and enhancing economic growth. This dual focus of equity (educational equity and economic competitiveness) is often presented as "harmonious" and complementary in institutional and government policy (Savage, 2013).

Higher education institutions are, however, problematic sites for equity initiatives to thrive in, given the competing and often conflicting interests (economic vs. social justice) (Barrow \& Grant, 2019). Equity in the academic achievement of Pacific students in the New Zealand higher education context continues to be a persistent and enduring challenge. Pacific academic achievement continues to lag behind that of other students, which has important ramifications for the achievement of social justice and social cohesion (Hart, 2018). Successive government policy and investment have been made into addressing the issue of inequities in education. Despite concentrated efforts by both government and higher education institutions in New Zealand, this has yet to lead to academic achievement of Pacific students at levels of parity with other students.

Pacific students at the University of Auckland are considered a target "equity group", which the university recognises as "more likely to have experienced one or more barriers to accessing and succeeding at the University, such as discrimination, marginalisation, under-representation, underachievement in school, and/or socioeconomic background" (University of Auckland, 2017, "Definition”, para. 4). At its most basic description (in practice), equity can be described as the investment of additional resources (funding and academic support programmes) to lift Pacific academic achievement so that it achieves parity with the performance of others (Ministry of Education, 2014).

Based on these challenges, Pacific students-a minority group within the university-have faced similar challenges to other minority group and Indigenous students globally in higher education (Naepi et al., 2017). In the literature, Pacific students are referred to as non-traditional students (Wong, 2018), working class (Walker \& Wilson-Strydom, 2017), low socioeconomic status (Universities New Zealand, 2018), minority ethnic (Blessinger et al., 2018), first in family (Wolfgramm-Foliaki, 2016) and ethnically diverse students (Allen \& Webber, 2019). The circumstances outlined above 
have led to the growth of equity (supplementary) initiatives designed to lift the academic performance of Pacific students. Across the university, these equity initiatives are known as Tuākana mentoring programmes-learning communities based on the tuakana-teina model (senior successful students supporting first year Māori and Pacific students) (Patterson, 2012). Essentially, Tuākana programmes are underpinned by Māori and Pacific concepts of relationality and privilege "Indigenous" Māori and Pacific ways of learning collectively. Māori and Pacific students who engage with these supplementary programmes have shown increased levels of academic achievement and retention (Universities New Zealand, 2018). However, given that many of these supplementary initiatives sit outside of the formal course or programme structure, there has been little to no university-wide evaluation of their impact. The structural location of Māori and Pacific support initiatives outside of the formal class structure has also been criticised as an ostracising of Indigenous (Māori and Pacific) pedagogies for teaching and learning (Williams, 2009).

Although the challenges raised in much of the literature regarding Pasifika success are related to student academic achievement, further implications arise for Pasifika academics navigating an academic trajectory, which requires further research. Much of the responsibility of Māori and Pasifika student support initiatives rests upon the shoulders of a very few Māori and Pasifika academics, mentors and student support staff. Again, the systemic challenges were made clear throughout the shell map making talanoa.

The hegemonic culture of the university needs to be challenged and changed. This needs to be done on a political level. Also, more Pasifika people need to be reflected in the higher hierarchy of this institution. (Pasifika staff)

It's not about being individualistic, you know, it's about being as a collective. I've always had that with me, it's not just me, on my own in that journey, I take the others with me, in particular my students, our students. (Pasifika staff)

\section{Navigating vision: Pasifika success as Pasifika}

The concept of self in Pacific societies as explained by Vaai and Nabobo-Baba (2017) is always a relational self, that is, one constituted by relations, in which the relational self is the part of the whole and the whole part of the self that is irreducible to the sum of its parts. The need for Indigenous epistemologies, ontologies and cosmological ideas and philosophy must be considered in global conversations; thus, consideration of local Indigenous understandings can support the way in which Pacific peoples are governed-taking ownership of decisions made with regard to land, seas, people and knowledge (Vaai \& Nabobo-Baba, 2017). The process of decolonisation of personhood is complex: the relational capacities that tie one's own subjectivity with collective identities, identities that are not always static or fixed. Here, we recognise the multiplicity (network of relations) of student, Pasifika, academic, kainga, personal and collective that intersect and cut across the act of wayfinding success as Pasifika. A Pasifika academic within the faculty summarised the key values reflected through talanoa:

Spirit, space and stewardship, it's about knowing where we come from, that kind of spiritual grounding, why we do our work. (Pasifika staff)

In an effort to decolonise personhood and reconceptualise Pasifika success, we share a poem that navigates the tensions, challenges and possibilities that Indigenous onto-epistemology offers us in confronting deficit theorising of Pacific peoples.

\section{Closing thoughts in poetry}

Priority learner

I'm a priority - that's what I'm told,

from the time, my mother held me in her arms, my father on his shoulders I stood, always trying to look beyond the horizon.

I'm a priority . . . learner, that's what I'm told, lowering my head, lower statistics reveal. This dichotomy is my story.

Priority learner to lift the outcomes of success, yet when I hear my grandfather's words I am a success in his eyes no less.

I am his story and he is mine, sensing more than education outcomes to define me. My wairua, my mauri, my life force.

Why the obsession to fix me?

Do I need to be fixed?

How is education shaped by taken for granted truths?

Am I reduce-able to one's perception taken in brief moments of assessment?

When in brief moments, solidified are my fears.

My fears to fail, to be another statistic another rhetoric, to persuade others that I need to be fixed, I am broken. 
The pieces of me, become pieces of youfragments in politics, policies of change and priority education plans.

What motivates you to help me to achieve higher degrees?

Responsive to policies, a responsive tap to funding ... and in changing my perceptions of wisdom, what it is to know, and who's knowledge matters most.

And still, with fire in my eyes, and warmth in my soul, the horizon I seek beyond one's control.

Responsive, inclusive, equality, terms coined in essentialising difference ... of culture, of colour, of ability . . my hopes, for education is that our eyes may meet in search of the horizon and for that moment, knowing the potential in me, is knowing the potential in you.

How can we navigate potentiality, to bring forth new subjectivities, what it means to lead and to know, to traverse tides of change in a globalised space, spaces together, yet spaces apart, spaces of difference and an openness to the unknown.

These are our indigenous histories, that bring us together, the vā of our ancestors, within me, within you, and the hope for wisdom for a people yet to come.

\section{Glossary}

Cook Island

Moana Nui

Māori

Aotearoa

awa

hauora

mauri

Pākehā

tangata whenua

wairua
(Matapo, 2017)

whenua

placenta or land (significant in Māori and Pacific tradition; the returning of the placenta to the land is a symbolic connection to land and ancestors)

\section{Marshallese}

meddo

rebbilib

Marshall Islands navigational chart focusing on a small group of islands

Marshall Islands navigational chart focusing on a large part of the archipelago

Pacific Islands (shared)

kainga

village, home, a collective from an academic perspective

maunga

mountain (important in the genealogy of Māori and Pacific peoples)

Pasifika

a term that represents a grouping together of Pacific Islands peoples living in New Zealand, either New Zealand born or migrant Pasifika ethnicities, including but not limited to Samoa, Tonga, Fiji, Cook Islands, Niue and Tuvalu

talanoa

a Pasifika concept of dialogical discussion or talk (Vaioleti, 2006)

\section{Samoan}

commonly used as Māori name for New Zealand; lit. "the land of the long white cloud"

river (connections to sea/ocean); as important as the mountain in the genealogy of Māori and Pacific peoples

Māori view of health exclusive to New Zealand that covers the physical, mental, social and spiritual needs and well-being of all

life essence, life force, energy, life principle

a person of predominantly European descent

Indigenous peoples of the land

spirit, soul; attitude aiga

itu

itulagi

\section{family (including extended family)}

side

worldview, one's thinking, including culture, family, religion, people, land, ancestors, ocean, language, spirit and the tualagi (Toso \& Matapo, 2018; Vaai \& Casimira, 2017); lit. "side of heaven"

lagi heavens

tangata o le people of the sea/ocean (Mallon moana et al., 2012)

tautua service

tualagi universe

vā relational space

\section{References}

Airini, Brown, D., Curtis, E., Johnson, O., Luatua, F., O'Shea, M., Rakena, O., Reynolds, G., Sauni, P., Smith, A., Huirua, T.S., Tarawa, M., \& UlugiaPua, M. (2009). Success for all: Improving Māori 
and Pasifika student success in degree-level studies (Milestone Report 8). NZCER Teaching and Learning Research Initiative. https://cdn.auckland. ac.nz/assets/education/about/schools/crstie/docs/ final-report-success-for-all-Dec09.pdf

Airini, Curtis, E., Townsend, S., Rakena, T. O., Brown, D., Sauni, P., Smith, A., Luatua, F., Reynolds, G., \& Johnson, O. (2011). Teaching for student success: Promising practices in university teaching. PacificAsian Education Journal, 23(1), 71-90. http:// www.victoria.ac.nz/learning-teaching/support/ approach/pasifika/teaching-for-student-success.pdf

Allen, J. M., \& Webber, M. (2019). Stereotypes of minorities and education. In S. Ratuva (Ed.), The Palgrave handbook of ethnicity (pp. 1-21). Palgrave Macmillan. http://doi.org/dh5c

Anae, M., Coxon, E., Finau, C., Mara, D., Wendt-Samu, T., \& Finau, C. (2001). Pasifika education research guidelines. Auckland UniServices Limited. https:// www.educationcounts.govt.nz/_data/assets/pdf_ file/0010/7669/pacrsrch--guide.pdf

Barrow, M., \& Grant, B. (2019). The uneasy place of equity in higher education: Tracing its (in)significance in academic promotions. Higher Education, 78(1), 133-147. http://doi.org/ggf625

Blessinger, P., Hoffman, J., \& Makhanya, M. (2018). Introduction to perspectives on diverse student identities in higher education. In J. Hoffman, P. Blessinger, \& M. Makhanya (Eds.), Perspectives on diverse student identities in higher education: International perspectives on equity and inclusion (pp. 1-11). Emerald Publishing Limited. http:// doi.org/dh5d

Chu, C., Abella, I. S., \& Paurini, S. (2013). Educational practices that benefit Pacific learners in tertiary education. Ako Aotearoa, National Centre for Tertiary Teaching Excellence. https://ako.ac.nz/assets/ Knowledge-centre/NPF-10-001A-Pasifika-Learnersand-Success-in-Tertiary-Education/6d7e53028e/ RESEARCH-REPORT-Educational-Practices-thatBenefit-Pacific-Learners-in-Tertiary-Education.pdf

Curtis, E., Townsend, S., \& Airini. (2012). Improving indigenous and ethnic minority student success in foundation health study. Teaching in Higher Education, 17(5), 589-602. http://doi.org/brwb

Deleuze, G., \& Guattari, F. (1987). A thousand plateaus: Capitalism and schizophrenia (B. Massumi, Trans). Continuum. (Original work published 1980)

Espinoza, O. (2010). Solving the equity/equality conceptual dilemma: A new goal-oriented model to approach analyses associated with different stages of the educational process. In J. Zajda (Ed.), Globalization, education and social justice (pp. 127-143). Springer Netherlands. http://doi. org/dc68fp

Farrelly, T., \& Nabobo-Baba, U. (2012, December 3-5). Talanoa as empathic research [Paper presentation]. International Development Conference 2012, Auckland, New Zealand. https://devnet. org.nz/wp-content/uploads/2018/07/Farrelly, $\% 20$ Trisia \% 20\&\%20Nabobo-Baba, \% 20Unaisi $\% 20$ Talanoa \%20as\%20Empathic\%20Research \%20 \%5Bpaper\%5D_0.pdf
Finau, S. (2014). Collective label of people from the Pacific Ocean proper. Enhancing màtauranga Māori and global indigenous knowledge. New Zealand Qualifications Authority. http://www. nzqa.govt.nz/assets/Maori/Te-Rautaki-Maori/ Publications/Enhancing-Mtauranga-Mori-andGlobal-Indigenous-Knowledge.pdf

Genz, J. H. (2018). Breaking the shell: Voyaging from nuclear refugees to people of the sea in the Marshall Islands. University of Hawai'i Press. http://doi. org/dh5f

Hart, C. (2018). Education, capabilities and sustainable development. In F. Comim, S. Fennell, \& P. Anand (Eds.), New frontiers of the capability approach (pp. 617-642). Cambridge University Press. http:// doi.org/djqh

Hau'ofa, E. (2008). We are the ocean: Selected works. University of Hawai'i Press.

Hunter, J., Hunter, R., Bills, T., Cheung, I., Hannant, B., Kritesh, K., \& Lachaiya, R. (2016). Developing equity for Pāsifika learners within a New Zealand context: Attending to culture and values. New Zealand Journal of Educational Studies, 51(2), 197-209. http://doi.org/dh5g

Lafaialii, S. (2012). Ua se ana: The promise of equity [Master's thesis, University of Auckland]. ResearchSpace. https://researchspace.auckland. ac.nz/handle/2292/17630

Lewis, D. (1994). We, the navigators: The Ancient art of landfinding in the Pacific (2nd ed.). University of Hawai'i Press.

Mallon, S., Māhina-Tuai, K., \& Salesa, D. (2012). Tangata o le moana: New Zealand and the people of the Pacific. Te Papa Press.

Marginson, S. (2011). Higher education and public good. Higher Education Quarterly, 65(4), 411433. http://doi.org/dw79h9

Matapo, J. (2017). Navigating leadership in Pasifika early childhood education: Traversing the tides of change. Не Кири, 5(1), 44-52. http://hdl.handle. net/2292/35052

Matapo, J. (2018). Traversing Pasifika education research in a post-truth era. Waikato Journal of Education = Te Hautaka Mātauranga o Waikato, 23(1), 139-146. http://doi.org/dh2t

Matapo, J. (2019, July 17). GCED-a Pasifika perspective. New Zealand National Commission for UNESCO on Global Citizenship Education. https:// unesco.org.nz/1843-2/

Matapo, J., \& Roder, J. (2017). Weaving our whāriki: Re-imagining progressive philosophy in Aotearoa New Zealand early childhood education. In C. Mutch, \& J. Tatebe (Eds.), Understanding enduring ideas in education: A response to those who "just want to be a teacher" (pp. 47-62). NZCER Press.

Mayeda, D. T., Keil, M., Dutton, H. D., \& Ofamo'Oni, I. F. H. (2014). "You've gotta set a precedent": Māori and Pacific voices on student success in higher education. AlterNative: An International Journal of Indigenous Peoples, 10(2), 165-179. http://doi.org/c9cg

Meyer, M. A. (2014). Indigenous epistemology: Spirit revealed. In T. Black, H. Murphy, C. Buchanan., 
W. Nuku., B. Ngaia (Eds.), Enhancing mātauranga Māori and global indigenous knowledge (151-165). NewZealand Qualifications Authority.https://www. nzqa.govt.nz/assets/Maori/Te-Rautaki-Maori/ Publications/Enhancing-Mtauranga-Mori-andGlobal-Indigenous-Knowledge.pdf

Mika, C. T. H., \& Matapo, J. (2018). The complexity of post-truth in research: An indigenous speculation. In M. A. Peters, S. Rider, \& T. Besley (Eds.), Post-truth, fake news: Viral modernity and higher education (pp. 187-196). Springer. http://doi.org/ dh5h

Ministry of Education. (2014). Tertiary Education Strategy. Ministry of Education; Ministry of Business, Innovation and Employment. https:// www.education.govt.nz/further-education/ policies-and-strategies/tertiary-education-strategy

Naepi, S., Stein, S., Ahenakew, C., \& Andreotti, V. (2017). A cartography of higher education attempts at inclusion and insights from Pasifika scholarship in Aotearoa New Zealand. In C. Reid \& J. Major (Eds.), Global teaching: Southern Perspectives on Working with Diversity (pp. 81-100). Palgrave Macmillan. http://doi.org/c83mdoi: 10.1057/978-1-137-52526-0

Patterson, S. (2012). The voices of Taciqu: Teaching and learning practices in non-lecture settings for Māori and Pasifika success in the first year of a Bachelor of Arts [Master's thesis, University of Auckland]. ResearchSpace. https://researchspace.auckland. ac.nz/handle/2292/19914

Pinar, W. (1995). Understanding curriculum: An introduction to the study of historical and contemporary curriculum discourses. Peter Lang.

Sakhiyya, Z., \& Rata, E. (2019). From “priceless” to "priced": The value of knowledge in higher education. Globalisation, Societies and Education, 17(3), 285-295. http://doi.org/dh5j

Salmi, J., \& Bassett, R. M. (2014). The equity imperative in tertiary education: Promoting fairness and efficiency. International Review of Education, 60(3), 361-377. http://doi.org/dh5k

Samu, T. L. M. W. (2006). The "Pasifika Umbrella" and quality teaching: Understanding and responding to the diverse realities within. Waikato Journal of Education = Te Hautaka Mātauranga o Waikato, 12, 35-50. http://doi.org/djqg

Savage, G. C. (2013). Tailored equities in the education market: Flexible policies and practices. Discourse: Studies in the Cultural Politics of Education, 34(2), 185-201. http://doi.org/dh5m

Savage, G. C., Sellar, S., \& Gorur, R. (2013). Equity and marketisation: Emerging policies and practices in Australian education. Discourse: Studies in the Cultural Politics of Education, 34(2), 161-169. http://doi.org/dh5n

Si'ilata, R. (2014). Va'a Tele: Pasifika learners riding the success wave on linguistically and culturally responsive pedagogies [Doctoral thesis, University of Auckland]. ResearchSpace. https://researchspace. auckland.ac.nz/bitstream/handle/2292/23402/ whole.pdf? sequence $=2$

Si'ilata, R., Samu, T. W., \& Siteine, A. (2018). The
Va'atele Framework: Redefining and transforming Pasifika education. In E. McKinley, E. Smith, \& L. Smith (Eds.), Handbook of indigenous education (pp. 907-936). Springer. http://doi.org/dh5p

Smith, L. (2012). Decolonizing methodologies: Research and indigenous peoples (2nd ed.). Zed Books

Spiller, C., Barclay-Kerr, H., \& Panoho, J. (2015). Wayfinding leadership: Ground breaking wisdom for developing leaders. Huia.

Tertiary Education Commission. (2018, April 6). Māori and Pasifika achievement is a learner success issue. https://www.tec.govt.nz/news-and-consultations/ archived-news/maori-and-pasifika-achievementlearner-success-issue/

Toso, V. M., \& Matapo, J. (2018). O le tatou itulagi i totonu o Aotearoa: Our life-worlds within New Zealand. The First Years: New Zealand Journal of Infant and Toddler Education = Nga tau tuatabi, 20(1), 3-5.

Turner, H., Rubie-Davies, C. M., \& Webber, M. (2015). Teacher expectations, ethnicity and the achievement gap. New Zealand Journal of Educational Studies, 50(1), 55-69. http://doi.org/gf2s22

Universities New Zealand. (2018). Achieving parity for Māori and Pasifika: The university sector view (UNZ Parity Discussion Paper No. 1). https://www. universitiesnz.ac.nz/sites/default/files/UNZ\%20 Parity \% 20Discussion \% 20Paper \%20One \% 20 \%28Aug\%202018\%29.pdf

University of Auckland. (2017). Equity policy. https:// www.auckland.ac.nz/en/about/the-university/ how-university-works/policy-and-administration/ equity/equity-policy-and-procedures-.html

Vaai, U. L., \& Casimira, A. (2017). Introduction: A relational renaissance. In U. L. Vaai \& A. Casimira (Eds.), Relational hermeneutics decolonising the mindset and the Pacific Itulagi (pp. 1-14). University of the South Pacific; Pacific Theological College.

Vaai, U. L., \& Nabobo-Baba, U. (2017). The relational self, decolonizing personhood in the Pacific. University of the South Pacific Press.

Vaioleti, T. M. (2006). Talanoa research methodology: A developing position on Pacific research. Waikato Journal of Education = Te Hautaka Mātauranga o Waikato, 12, 21-34. http://doi.org/c6mj

Walker, M. (2006). Higher education pedagogies. McGraw-Hill Education.

Walker, M., \& Wilson-Strydom, M. (2017). Socially just pedagogies, capabilities and quality in higher education: Global perspectives. Palgrave. http:// doi.org/dh5r

Williams, N. (2009). A view from the back, times between spaces: Equality of educational opportunity and Pacific students at a university [Doctoral thesis, University of Auckland]. ResearchSpace. https:// researchspace.auckland.ac.nz/handle/2292/5698

Wolfgramm-Foliaki, E. (2016). "Do not assume we know": Perspectives of Pacific Island first in the family students. In L. Santamaria \& A. Santamaria (Eds.), Culturally responsive leadership in higher education: Promoting access, equity, and improvement (pp. 123-135). Routledge. http://doi.org/ $\mathrm{dh} 23$ 
Wong, B. (2018). By chance or by plan?: The academic success of nontraditional students in higher education. AERA Open, 4(2), pp. 1-14. http://doi.org/ djqj 